\title{
Coffee Induces Breast Cancer Resistance Protein Expression in Caco-2 Cells
}

\author{
Marina Isshiki, ${ }^{a}$ Kazuo Umezawa, ${ }^{b}$ and Hiroomi TAmURA $*, a$ \\ ${ }^{a}$ The Graduate School of Pharmaceutical Sciences, Keio University; and ${ }^{b}$ The Graduate School of Science and \\ Technology, Keio University; Tokyo 105-8512, Japan. \\ Received June 15, 2011; accepted July 12, 2011; published online July 14, 2011
}

\begin{abstract}
Coffee is a beverage that is consumed world-wide on a daily basis and is known to induce a series of metabolic and pharmacological effects, especially in the digestive tract. However, little is known concerning the effects of coffee on transporters in the gastrointestinal tract. To elucidate the effect of coffee on intestinal transporters, we investigated its effect on expression of the breast cancer resistance protein (BCRP/ABCG2) in a human colorectal cancer cell line, Caco-2. Coffee induced BCRP gene expression in Caco-2 cells in a coffee-dose dependent manner. Coffee treatment of Caco-2 cells also increased the level of BCRP protein, which corresponded to induction of gene expression, and also increased cellular efflux activity, as judged by Hoechst33342 accumulation. None of the major constituents of coffee tested could induce BCRP gene expression. The constituent of coffee that mediated this induction was extractable with ethyl acetate and was produced during the roasting process. Dehydromethylepoxyquinomicin (DHMEQ), an inhibitor of nuclear factor (NF)- $\kappa \mathrm{B}$, inhibited coffee-mediated induction of BCRP gene expression, suggesting involvement of NF- $\kappa \mathrm{B}$ in this induction. Our data suggest that daily consumption of coffee might induce BCRP expression in the gastrointestinal tract and may affect the bioavailability of BCRP substrates.
\end{abstract}

Key words coffee; breast cancer resistance protein; Caco-2; nuclear factor $\kappa \mathrm{B}$

Coffee is a beverage that is consumed world-wide and that induces a series of metabolic and pharmacological effects, especially in the digestive tract. A moderate intake of coffee has been linked to reduced risk of chronic diseases, and epidemiological studies have now shown that coffee consumption is associated with a lower risk of certain types of cancers, particularly colorectal cancers. ${ }^{1,2}$ In addition, evidence from a number of animal studies has provided further support for a potential chemoprotective effect of coffee; both coffee and constituents of coffee show protective effects against the action of specific carcinogens such as nitrosoamines and 1,2-dimethylhydrazine. ${ }^{3,4)}$ Several studies have also demonstrated the effects of coffee on hepatic enzymes involved in the detoxification of carcinogens, such as cytochrome P450 1A2 (CYP1A2), uridine 5'-diphosphate (UDP)-glucuronosyl transferases (UGTs) and glutathione $S$ transferases (GSTs). ${ }^{5-7)}$ We have reported that coffee reduces sulfoconjugation of 1-naphthol and estradiol in a human colon carcinoma cell line, Caco-2 ${ }^{8,9)}$ However, little is known about the effects of coffee on gastrointestinal transporters.

The breast cancer resistance protein, BCRP, is a half-molecule ATP-binding cassette transporter that facilitates the efflux of various drugs, including anticancer agents. Expression of BCRP can thus confer a multidrug resistance phenotype on cancer cells. ${ }^{10)} \mathrm{BCRP}$ is highly expressed in placental syncytiotrophoblasts, in the apical membrane of the epithelium in the small intestine, in the liver canalicular membrane, and at the luminal surface of the endothelial cells of human brain microvessels. ${ }^{11)}$ This strategic and abundant tissue localization indicates that BCRP plays an important role in absorption, distribution, and elimination of drugs and environmental chemicals that are BCRP substrates, such as antibiotics, topotecan, and dietary carcinogens. As a first step in elucidation of the effects of coffee on intestinal transporters, we examined its effects on BCRP using the human colon car- cinoma cell line, Caco-2. We found as a first time that coffee induced BCRP gene expression in Caco-2 cells via nuclear factor (NF)- $\kappa \mathrm{B}$-mediated transcriptional control.

\section{MATERIALS AND METHODS}

Materials Reagents for the polymerase chain reaction (PCR) were obtained from Applied Biosystems, Inc. (Warrington, U.K.). Caco-2 cells at passage 40 were obtained from the RIKEN Cell Bank (Tokyo, Japan). Reagents for Western blotting were purchased from Thermo Scientific Inc. (Tokyo, Japan). The monoclonal anti-BCRP antibody was purchased from Kamiya Biomedical Co. (Seattle, WA, U.S.A.). Hoechst 33342 was obtained from Dojin Chemicals (Tokyo, Japan). Ko143 and other chemicals were purchased from Sigma Chemicals (St. Louis, MO, U.S.A.). Columbian Arabica coffee beans were purchased from Nakaya Coffee (Tokyo, Japan).

Cell Culture Caco-2 cells were grown in 12-well plates (Iwaki, Tokyo, Japan) in $1 \mathrm{ml}$ of minimum essential medium (MEM), supplemented with $10 \%$ fetal bovine serum, $2 \mathrm{~mm}$ glutamine, $10 \mathrm{U} / \mathrm{ml}$ penicillin, $10 \mathrm{U} / \mathrm{ml}$ streptomycin, and additional non-essential amino acids. The cells were seeded at a concentration of $5 \times 10^{5}$ cells $/ \mathrm{ml}$ and grown to confluence (5-6 d) in an incubator at $37^{\circ} \mathrm{C}$, in a humidified atmosphere containing $5 \% \mathrm{CO}_{2}$. Subsequently, the cells were further cultivated for up to 3 weeks to allow functional differentiation. ${ }^{12)}$ The medium was changed every $4-5 \mathrm{~d}$.

Preparation of Coffee Extract Blended coffee powder (Arabica beans) was obtained from Starbucks Coffee Japan (Tokyo, Japan). Coffee extracts were prepared by a common method, in which $8 \mathrm{~g}$ of powder was extracted with $140 \mathrm{ml}$ hot water $\left(95^{\circ} \mathrm{C}\right)$. The extract was then filtered, divided into small aliquots and stored at $-80^{\circ} \mathrm{C}$ until used. Undiluted extract, with a dry weight of $8.4 \mathrm{mg} / \mathrm{ml}$, was assigned a concentration of $100 \%(\mathrm{v} / \mathrm{v})$. 
Roasting of Coffee Beans Colombian Arabica coffee beans were roasted in a roaster at $220^{\circ} \mathrm{C}$ for $5,10,15,20$, and $25 \mathrm{~min}$. At each roasting time, coffee beans were pulverized, and $8 \mathrm{~g}$ of the sample was extracted with $140 \mathrm{ml}$ of boiling water.

Analysis of BCRP Gene Expression Total RNA was isolated from the cultured cells using guanidinium thiocyanate-phenol-chloroform extraction. First strand cDNA was synthesized from $10 \mu \mathrm{g}$ of total RNA using 1 unit of MMLV reverse transcriptase with oligo (dT) primers, according to the manufacturer's protocol. PCR was performed with Taq DNA polymerase using this cDNA as a template. The primers used for the amplification of BCRP cDNA were designed based on the published sequence as follows $\left(5^{\prime}\right.$ to $\left.3^{\prime}\right)$ : TGTCACAAGGAAACACCAATGG and GATGGCGTTGAGACCAGGTT. Quantitative real-time PCR was performed in an ABI 7300 thermal cycler using a SYBR green PCR core reagent kit (Applied Biosystems Inc., Warrington, U.K.). Samples were denatured at $94^{\circ} \mathrm{C}$ for $10 \mathrm{~min}$, and cDNA products were amplified using 40 cycles of denaturation at $94{ }^{\circ} \mathrm{C}$ for $30 \mathrm{~s}$ followed by annealing and extension at $60{ }^{\circ} \mathrm{C}$ for $60 \mathrm{~s}$. The initial amounts of mRNA were calculated according to the cycle threshold method. ${ }^{13)}$ The mRNA levels were normalized to $18 \mathrm{~S}$ RNA levels, which were quantified using real-time PCR.

Western Blot Analysis Cells were lysed for $30 \mathrm{~min}$ on ice in a buffer containing $20 \mathrm{~mm} N$-(2-hydroxyethyl)piperazine- $N$-ethanesulfonic acid (HEPES) (pH 7.8), $500 \mathrm{~mm}$ $\mathrm{NaCl}, 0.2 \mathrm{~mm}$ ethylenediaminetetraacetic acid (EDTA), $1 \%$ NP-40, and protease inhibitors. The cell lysates were centrifuged at $4000 \times \boldsymbol{g}$ for $10 \mathrm{~min}$ at $4{ }^{\circ} \mathrm{C}$ and the supernatants were collected. Protein lysates were subjected to $12 \%$ sodium dodecyl sulfate (SDS)-polyacrylamide gel electrophoresis (PAGE) and electrotransferred onto Immobilon P membranes (Millipore, Bedford, MA, U.S.A.) before incubation with primary antibody (anti-BCRP antibody) followed by incubation with horseradish peroxidase (HRP)-conjugated anti-rabbit immunoglobulin G (IgG) secondary antibody. Protein bands were detected using the ECL reagent (Thermo Scientific, Tokyo, Japan) and were quantified by densitometric analysis using an imaging analyzer (BioRad VersaDoc imaging system). Protein concentrations were determined using the Bradford assay.

Accumulation of Hoechst33342 For estimation of BCRP activity the fluorescent dye Hoechst33342 was used as a BCRP substrate. ${ }^{14)}$ Cells were seeded in 96-well plates and cultivated for 3 weeks to allow functional differentiation. The cells were incubated with coffee at various concentrations for 24 or $48 \mathrm{~h}$. The cells were then washed with PBS and incubated for $30 \mathrm{~min}$ at $37^{\circ} \mathrm{C}$ with $100 \mu \mathrm{l}$ of MEM containing Hoechst33342 $(5 \mu \mathrm{M})$. Solutions were then removed and the uptake process was terminated using ice-cold stop solution. The cells were later lysed with $100 \mu \mathrm{l}$ of $0.1 \%$ Triton-X in $0.3 \mathrm{M}$ sodium hydroxide solution. Intracellular accumulation of Hoechst33342 dye was measured at $460 \mathrm{~nm}$ after excitation at $355 \mathrm{~nm}$ using a microtiter plate reader (WALLAC ARVO1420, PerkinElmer, MA, U.S.A.). The contribution of BCRP to transport was verified using Ko143, a selective BCRP inhibitor. ${ }^{15)}$

Statistical Analysis Data were statistically analyzed using Student's $t$ tests. Results were considered significant when $p<0.05$.
(A)

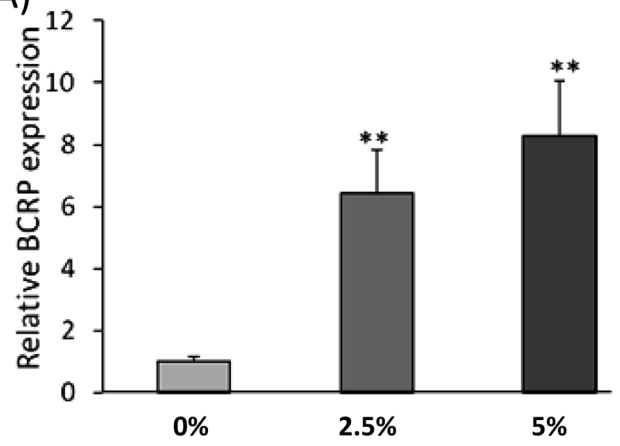

(B)

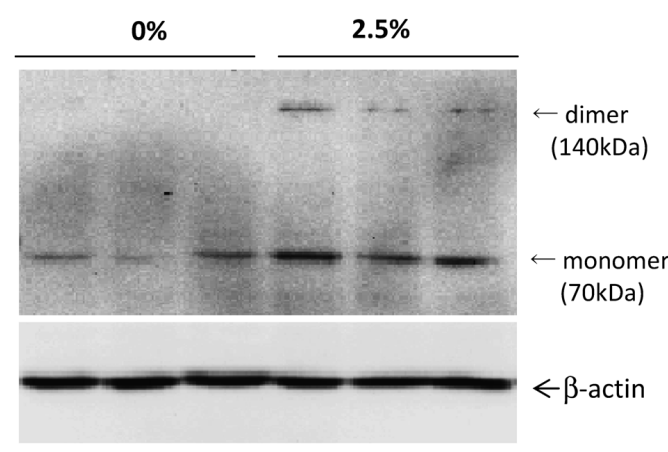

(C)

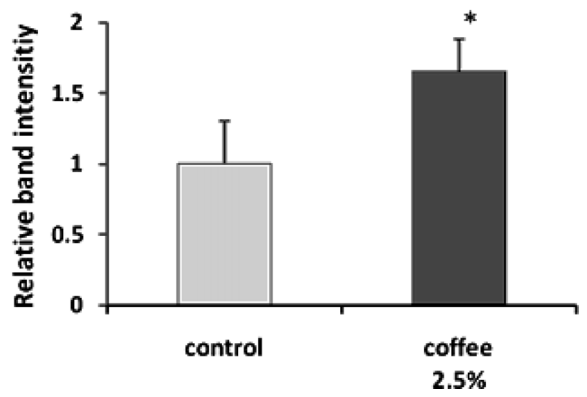

Fig. 1. Induction of BCRP Expression in Caco-2 Cells by Coffee

(A) Total RNA was isolated from Caco-2 cells that were treated with the indicated concentrations of coffee for $24 \mathrm{~h}$, and was used for quantitative real-time PCR analysis of BCRP gene expression. The values are calculated as means \pm S.D. of three experiments and are presented relative to the control value which was set at 1 . $* * p<0.01$. (B) Caco-2 cells were left untreated or were treated with $2.5 \%$ coffee for $24 \mathrm{~h}$. Whole cell lysate $(15 \mu \mathrm{g}$ each) were subjected to immunoblot analysis of BCRP as described in Materials and Methods. Immunoblotting of $\beta$-actin was used as a loading control. (C) Densitometric analysis was performed on the data in (B). The ratio of BCRP (monomer) $/ \beta$-actin was quantified and is expressed relative to control $(n=3) . * p<0.05$. 


\section{RESULTS}

Effect of Coffee on the Expression of BCRP in Caco-2 Cells Caco- 2 cells were incubated with coffee for $24 \mathrm{~h}$ and the expression of the BCRP gene was examined using realtime PCR (Fig. 1A). BCRP gene expression was increased 8fold over that of control by $5 \%$ coffee. Coffee induction of BCRP was detected at an early stage of culture $(6 \mathrm{~h})$ (data not shown). Western blot analysis confirmed that the BCRP protein was also elevated in the coffee-treated Caco-2 cells (Figs. 1B, C). The effect of coffee on cellular efflux activity was then measured using the Heochst33342 exclusion assay. As shown in Fig. 2, coffee enhanced the exclusion of Hoechst33342 from Caco- 2 cells in a dose-dependent manner. This efflux activity was abolished by a selective inhibitor of BCRP, Ko143 (Fig. 2).

Chemical Properties of Active Coffee Compounds Although there are several major constituents of coffee extracts such as caffeine, chlorogenic acid, caffeic acid and trigoneline that exhibit specific physiological activities, these com-

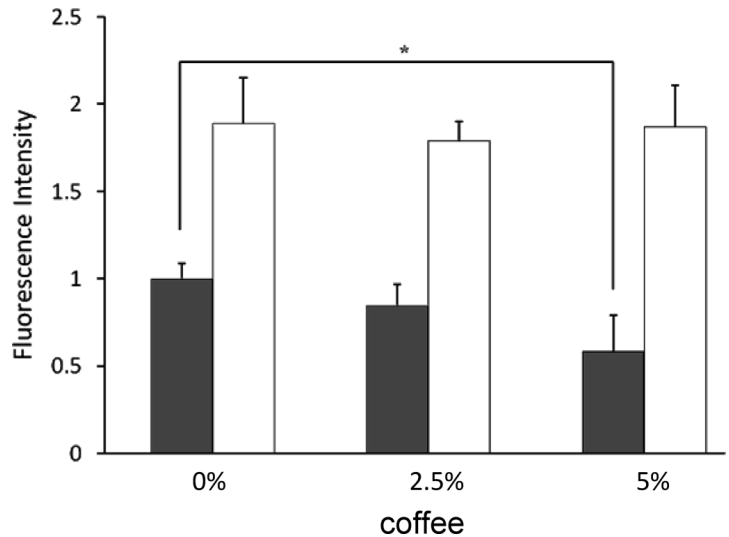

Fig. 2. Effect of Coffee on the Accumulation of Hoechst33342 in Caco-2 Cells

Caco- 2 cells were treated with coffee for $24 \mathrm{~h}$. The cells were then washed and incubated with $5 \mu \mathrm{M}$ Hoechst 33342 with or without $10 \mu \mathrm{M}$ of the selective BRCP inhibito Ko143 for $30 \mathrm{~min}$. The cells were lysed and the intracellular accumulation of Hoechst 33342 dye was measured at $460 \mathrm{~nm}$ after excitation at $355 \mathrm{~nm}$ using a microtiter plate reader. Black bars, without Ko143; open bars, with Ko143 $(n=3)$ $* p<0.05$.

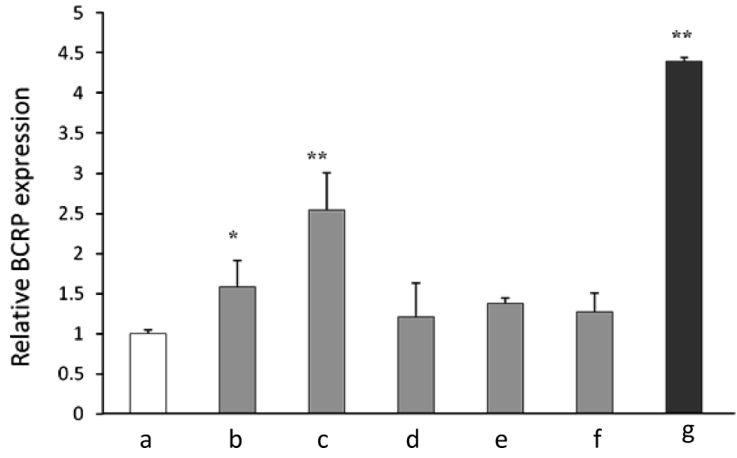

Fig. 3. Separation of BCRP Gene Expression-Inducing Activity of Coffee by Solvent Extraction

Coffee $(500 \mu 1)$ was sequentially extracted with equal volumes of $n$-hexane, ethyl acetate, chloroform and $n$-butanol. Organic and aqueous phases were then concentrated by evaporation and dissolved in an equal volume of DMSO. The resulting effect on BCRP gene expression in Caco-2 cells were then measured using real-time PCR. (a) control (0.1\% DMSO), (b) $n$-hexane extract, (c) ethyl acetate extract, (d) chloroform extract, (e) $n$-butanol extract, (f) aqueous phase, (g) $2.5 \%$ coffee. Data shown are expressed relative to the control $(n=3)$. $* p<0.05, * * p<0.01$. pounds did not show any effect on BCRP gene expression (data not shown). Therefore, to further characterize the active constituents of coffee, coffee was sequentially extracted with an equal volume of the solvents $n$-hexane, ethyl acetate, chloroform and $n$-butanol, and the BCRP-inducing activity of each extract was then measured. Induction of BCRP gene expression was mainly detected in the ethyl acetate extract and slight induction was also detected in the $n$-hexane extract (Fig. 3).

Many phenolic constituents and Maillard reaction products are known to form during the coffee roasting process. ${ }^{16-18)}$ To examine the possibility that active, BCRP-gene-inducing components are formed during the roasting process, we assayed the activity of extracts of green beans that had undergone varying degrees of roasting before brewing. We tested extracts of beans that had been roasted for times ranging from 0 to $20 \mathrm{~min}$. Increasing the degree of roasting of the extract $(2.5 \% \mathrm{v} / \mathrm{v})$ resulted in an increased ability of the extract to induce BCRP gene expression (Fig. 4). The maximum gene inducing activity was observed at a roasting time of $20 \mathrm{~min}$. A slight gene-inducing activity was also detected in the green beans.

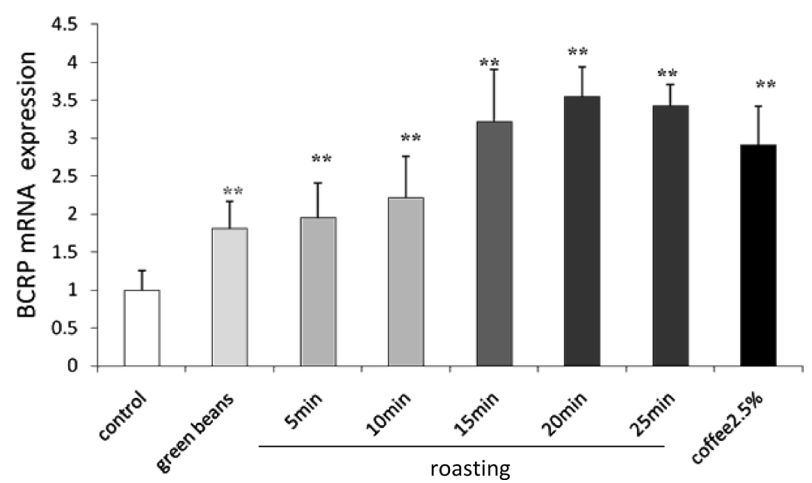

Fig. 4. Enhanced Induction of BCRP Gene Expression by Increasing the Roasting Time

Arabica coffee beans were roasted at $220^{\circ} \mathrm{C}$ for $5,10,15,20$ or $25 \mathrm{~min}$ and the beans were pulverized and extracted with boiling water as described in Materials and Methods. Extracts were added to the culture medium at a concentration of $2.5 \%(\mathrm{v} / \mathrm{v})$ and were incubated with the cells for $24 \mathrm{~h}$. BCRP mRNA was then measured using realtime PCR. Data are expressed relative to non-roasted control values. $* * p<0.01$. Control means no addition of coffee or extracts.

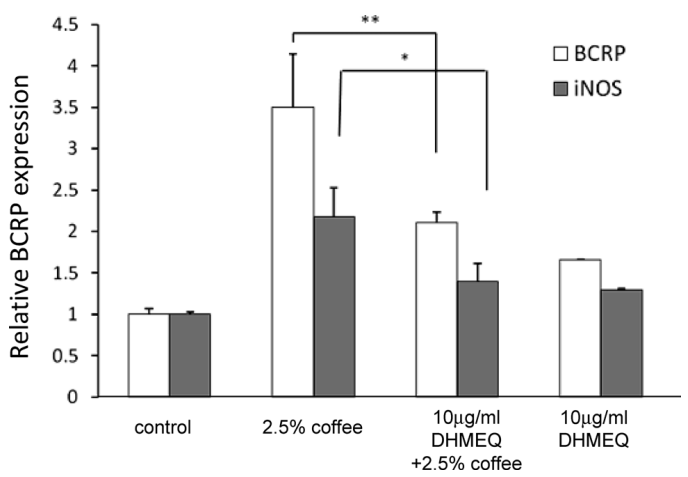

Fig. 5. Involvement of NF- $\kappa \mathrm{B}$ in the Induction of BCRP Gene Expression by Coffee

Caco-2 cells were not treated, or were treated with $2.5 \%$ coffee, with or without $10 \mu \mathrm{g} / \mathrm{ml}$ of the NF- $\kappa$ B inhibitor DHMEQ for $24 \mathrm{~h}$. Expression of the BCRP and iNOS genes was then measured using quantitative real-time PCR. Bars signify means and standard deviations of 3 measurements. $* p<0.05$, $* * p<0.01$. Control means no addition of coffee or extracts. 
Involvement of NF- $\mathrm{KB}$ in Coffee-Mediated Induction of BCRP Gene Expression in Caco-2 Cells Recently Wang et al. reported that $\mathrm{NF}-\kappa \mathrm{B}$ can activate BCRP gene expression through binding to a specific site within the $B C R P$ promoter in MCF-7 cells. ${ }^{19)}$ Since we found that coffee could induce the expression of the inducible NO synthase (iNOS) gene, which is up-regulated via activation of NF- $\kappa \mathrm{B}$ (Fig. 5), we investigated the possible involvement of NF- $\kappa \mathrm{B}$ in coffeemediated induction of the BCRP gene. As shown in Fig. 5, dehydromethylepoxyquinomicin (DHMEQ), an NF- $\kappa \mathrm{B}$ inhibitor, ${ }^{20)}$ reduced coffee-mediated induction of the BCRP gene as well as of the iNOS gene.

\section{DISCUSSION}

Here, we reported that coffee constituent(s) induced BCRP expression in the human intestinal model Caco- 2 cells. The active components in coffee were extractable with ethyl acetate and were formed during the roasting process.

BCRP is highly expressed in the gastrointestinal tract, suggesting that it plays a role in limiting the oral absorption of its substrates. Indeed, several studies indicated that intestinal uptake of antibiotics, topotecan, flavonoids, and dietary carcinogens such as PhIP and aflatoxin B1, was increased in the presence of BCRP inhibitors or in BCRP knock-out mice, providing strong evidence for the role of BCRP in oral drug absorption. ${ }^{21)}$ Our data would suggest that daily consumption of several cups of coffee would induce BCRP expression in the gastrointestinal tract. This expression would decrease the bioavailability of drugs and environmental chemicals including carcinogens, which are substrates of BCRP. This modification of BCRP activity by coffee might be linked to the results of epidemiological studies which indicate association of coffee consumption with a lower risk of certain types of cancers, particularly colorectal cancers. ${ }^{22)}$ Evidence from a number of animal studies has provided further support for a potential chemoprotective effect of coffee; coffee shows protective effects against the action of specific carcinogens such as PhIP and nitrosoamines. ${ }^{5)}$

A variety of studies propose that caffeine, as well as various diterpenes, are the most potent biologically active constituents of coffee. ${ }^{23)}$ However, we found that none of the major coffee components; caffeine, chlorogenic acid, caffeic acid or trigonelline could induce BCRP expression. We demonstrated that the active constituents of coffee are formed during the roasting process and are extractable with ethyl acetate (Figs. 3, 4). Since antioxidant phenolic constituents and Maillard reaction products are formed during the roasting process, ${ }^{16)}$ we speculate that one of these products may be a candidate for the active constituent(s) in coffee. Purification and identification of these components are now in progress in our laboratory.

Recent studies have reported the regulation of BCRP gene expression by nuclear transcription factors: Nrf2, a redoxsensing transcription factor, up-regulates BCRP expression in cancer cells, ${ }^{24)}$ the arylhydrocarbon receptor (AhR) is involved in the induction of BCRP in LS174T cells, ${ }^{25)}$ and NF$\kappa \mathrm{B}$ activates BCRP expression in MCF-7 cells. ${ }^{19}$ In this report we also demonstrated the involvement of NF- $\kappa \mathrm{B}$ in coffee-mediated induction of BCRP gene expression in Caco-2 cells using the NF- $\kappa$ B-specific inhibitor, DHMEQ (Fig. 5).
In contrast, Paur et al. reported that coffee extracts inhibited LPS-induced NF- $\kappa$ B activation in peripheral blood cells. ${ }^{17,18)}$ Active components in coffee extracts might compete with LPS-mediated signals that are necessary for activation of the BCRP gene. Further characterization of the mechanism of activation of NF- $\kappa$ B by coffee should be performed.

In conclusion, we found that coffee constituent(s) produced during roasting process induced BCRP gene expression via $\mathrm{NF}-\kappa \mathrm{B}$ activation in human intestinal model Caco-2 cells. This suggests that daily coffee consumption may affect bioavailability of compounds that are substrates for BCRP, thereby influence the toxicity or the activity of these compounds to the body.

Acknowledgements We thank Dr. K. Oka for helpful discussion. We are grateful to Dr. Kiuchi and Dr. Narukawa for their generous help. This work was supported in part by a Grant-in-Aid from the Ministry of Education, Culture, Sports, Science and Technology of Japan.

\section{REFERENCES}

1) Inoue M., Tajima K., Hirose K., Hamajima N., Takezaki T., Kuroishi T., Tominaga S., Cancer Causes Control, 9, 209-216 (1998).

2) Giovannucci E., Am. J. Epidemiol., 147, 1043-1052 (1998).

3) Tanaka T., Nishikawa A., Shima H., Sugie S., Shinoda T., Yoshimi N., Iwata H., Mori H., Basic Life Sci., 52, 429-440 (1990).

4) Gershbein L. L., Anticancer Res., 14(3A), 1113-1116 (1994).

5) Turesky R. J., Richoz J., Constable A., Curtis K. D., Dingley K. H., Turteltaub K. W., Chem. Biol. Interact., 145, 251-265 (2003).

6) Cavin C., Holzhäuser D., Constable A., Huggett A. C., Schilter B., Carcinogenesis, 19, 1369-1375 (1998).

7) Cavin C., Holzhaeuser D., Scharf G., Constable A., Huber W. W. Schilter B., Food Chem. Toxicol., 40, 1155-1163 (2002).

8) Okamura S., Suzuki K., Yanase M., Koizumi M., Tamura H. O., Biol. Pharm. Bull., 28, 271-274 (2005).

9) Saruwatari A., Isshiki M., Tamura H., Biol. Pharm. Bull., 31, 21312136 (2008).

10) Noguchi K., Katayama K., Mitsuhashi J., Sugimoto Y., Adv. Drug Deliv. Rev., 61, 26-33 (2009).

11) Mao Q., Unadkat J. D., AAPS J., 7, E118-E133 (2005).

12) Jumarie C., Malo C., J. Cell. Physiol., 149, 24-33 (1991).

13) Higuchi R., Fockler C., Dollinger G., Watson R., Biotechnology (N.Y.), 11, 1026-1030 (1993).

14) Scharenberg C. W., Harkey M. A., Torok-Storb B., Blood, 99, 507512 (2002).

15) Allen J. D., van Loevezijn A., Lakhai J. M., van der Valk M., van Tellingen O., Reid G., Schellens J. H., Koomen G. J., Schinkel A. H., Mol. Cancer Ther., 1, 417-425 (2002).

16) del Castillo M. D., Ames J. M., Gordon M. H., J. Agric. Food Chem., 50, 3698-3703 (2002).

17) Paur I., Balstad T. R., Blomhoff R., Free Radic. Biol. Med., 48, 1218 1227 (2010).

18) Paur I., Balstad T. R., Kolberg M., Pedersen M. K., Austenaa L. M., Jacobs D. R. Jr., Blomhoff R., Cancer Prev. Res. (Philadelphia), 3, $653-663$ (2010).

19) Wang X., Wu X., Wang C., Zhang W., Ouyang Y., Yu Y., He Z., FEBS Lett., 584, 3392-3397 (2010).

20) Ariga A., Namekawa J., Matsumoto N., Inoue J., Umezawa K., J. Biol. Chem., 277, 24625-24630 (2002).

21) Robey R. W., To K. K., Polgar O., Dohse M., Fetsch P., Dean M., Bates S. E., Adv. Drug Deliv. Rev., 61, 3-13 (2009).

22) Galeone C., Turati F., La Vecchia C., Tavani A., Cancer Causes Control, 21, 1949-1959 (2010).

23) Higdon J. V., Frei B., Crit. Rev. Food Sci. Nutr., 46, 101-123 (2006).

24) Singh A., Wu H., Zhang P., Happel C., Ma J., Biswal S., Mol. Cancer Ther., 9, 2365-2376 (2010).

25) Tompkins L. M., Li H., Li L., Lynch C., Xie Y., Nakanishi T., Ross D. D., Wang H., Biochem. Pharmacol., 80, 1754-1761 (2010). 